\title{
Faktor-Faktor Yang Berhubungan Dengan Pengelolaan Air Minum Rumah Tangga Di Desa Tambang Emas Kabupaten Merangin
}

\section{Factors Related to the Management of Household Drinking Water in the Gold Mining Village, Merangin Regency}

\author{
Yuni Fitri Ningsih" ${ }^{1}$, Eti Kurniawati ${ }^{2}$, Suroso $^{3}$ \\ 1,2Sekolah Tinggi Ilmu Kesehatan Harapa Ibu Jambi \\ ${ }^{3}$ Dinas Kesehatan Provinsi Jambi \\ *Koresponding Penulis : ${ }^{1}$ yunifitriningsih24@gmail.com
}

\begin{abstract}
ABSTRAK
Air merupakan sumber daya alam yang diperlukan untuk hajad hidup orang banyak, bahkan oleh semua makhluk hidup. Ketersediaan sarana ini jika kondisinya tidak memenuhi syarat maka dapat memungkinkan terjadinya pencemaran, sehingga dapat menimbulkan penyakit-penyakit yang berhubungan dengan air seperti penyakit diare, kolera, cacingan dan penyakit kulit. Penelitian ini bertujuan untuk mengetahui fator-faktor yang berhubungan dengan pengelolaan air minum rumah tangga di Desa Tambang Emas. Penelitian ini merupakan penelitian kuantitatif dengan desain cross sectional. Penelitian dilakukan di Dusun Rimba Mulya Desa Tambang Emas pada bulan Juli s/d Agustus 2020. Sampel penelitian adalah ibu rumah tangga (IRT) di Dusun Rimba Mulya Desa Tambang Emas sebanyak 73 orang. Teknik pengambilan sampel menggunakan teknik simple random sampling. Instrumen yang digunakan adalah kuesioner. Teknik pengumpulan data dengan metode wawancara. Data dianalsis menggunakan uji statistik yaitu uji chi-square. Hasil penelitian diketahui bahwa $50,7 \%$ responden memiliki perilaku baik dalam pengelolaan air minum rumah tangga, sebanyak $67,1 \%$ responden memiliki pengetahuan baik, sebanyak 57,5\% responden memiliki sikap baik dan sebanyak 46,6\% responden memiliki peran petugas kesehatan baik. Hasil bivariat menunjukkan bahwa ada hubungan antara pengetahuan $(\mathrm{p}=0,001)$, sikap $(\mathrm{p}=0,046)$ dan peran petugas kesehatan $(\mathrm{p}=0,045)$ dengan pengelolaan air minum rumah tangga di Desa Tambang Emas tahun 2020. Diharapkan kepada puskesmas untuk memberikan penyuluhan kesehatan kepada ibu-ibu rumah tangga. Materi penyuluhan yang dapat diberikan antara lain caracara pengelolaan air minum rumah tangga serta penyakit-penyakit yang disebabkan oleh air minum yang tidak dikelola dengan baik.
\end{abstract}

\section{Kata Kunci : Pengelolaan Air Minum, Pengetahuan, Sikap, Peran Petugas Kesehatan}

Abstract
Water is a natural resource that is necessary for the livelihood of many people,
even by all living things. The availability of this facility, if the conditions do not
meet the requirements, may cause pollution, which can cause water-related 
Journal of Healthcare Technology and Medicine Vol. 6 No. 2 Oktober 2020

Universitas Ubudiyah Indonesia

e-ISSN : 2615-109X

diseases such as diarrhea, cholera, worms and skin diseases. This study aims to determine the factors related to the management of household drinking water in the Gold Mine Village. This research is a quantitative study with a cross sectional design. The research was conducted in Rimba Mulya Hamlet, Tambang Emas Village in June 2020. The research sample was 73 housewives in Rimba Mulya Hamlet, Tambang Emas Village. The sampling technique used simple random sampling technique. The instrument used was a questionnaire. The data collection technique used the interview method. The data were analyzed using a statistical test, namely the chi-square test. The results showed that $50.7 \%$ of respondents had good behavior in household drinking water management, $67.1 \%$ of respondents had good knowledge, $57.5 \%$ of respondents had good attitudes and as many as $46.6 \%$ of respondents had the role of good health workers. . The bivariate results show that there is a relationship between knowledge $(p=0.001)$, attitude $(p=0.046)$ and the role of health workers $(p=0.045)$ with household drinking water management in Gold Mining Village in 2020. It is hoped that the puskesmas will provide health education to housewives. Extension materials that can be provided include ways of managing household drinking water and diseases caused by drinking water that is not properly managed.

Keywords: Drinking Water Management, Knowledge, Attitudes, Role of Health Officers

\section{PENDAHULUAN}

Pengelolaan air minum dan makanan rumah tangga adalah proses pengolahan, penyimpanan, dan pemanfaatan air minum dan air yang digunakan untuk produksi makanan dan keperluan oral lainnya, serta pengolahan makanan yang aman di rumah tangga, meliputi prinsip hygiene sanitasi pangan, yaitu pemilihan bahan makanan, penyimpanan bahan makanan, pengolahan bahan makanan, penyimpanan makanan, pengangkutan makanan, dan penyajian makanan (Kemenkes, 2015).

Data Kemenkes RI tahun 2019 menunjukkan bahwa persentase sarana air minum dngan resiko rendah dan sedang sebesar 45,77\%. Sedangkan rumah tangga yang memiliki akses terhadap sumber air minum layak sebesar 73,65\%. Di Provinsi Jambi pada tahun 2019 menunjukkan bahwa persentase sarana air minum dngan resiko rendah dan sedang sebesar $95,77 \%$. Persentase sarana air minum yang memenuhi syarat sebesar 94,62\%. Presentase rumah tangga yang memiliki akses terhadap sumber air minum layak pada tahun 2017 sebesar 67,73\%, tahun 2018 sebesar 66,66\% dan tahun 2019 sebesar 62,94\%. Hal tersebut menunjukkan bahwa rumah tangga yang memiliki akses terhadap sumber air minum laya di 
Journal of Healthcare Technology and Medicine Vol. 6 No. 2 Oktober 2020

Universitas Ubudiyah Indonesia

e-ISSN : 2615-109X

Provinsi Jambi setiap tahun mengalami penurunan (Kemenkes, 2019). Data Dinas Kesehatan Kabupaten Merangin menunjukkan bahwa penduduk dengan akses berkelanjutan terhadap air minum berkualitas (layak) tahun 2018 sebesar 78,7\%.

Puskesmas Tambang Emas merupakan salah satu puskesmas yang ada di Kabupaten Merangin dengan jumlah penduduk sebanyak 17.712 penduduk. Jika dilihat data yang ada di Dinas Kesehatan menunjukkan bahwa sebagian besar penduduk menggunakan sumur gali dengan pompa sebesar 10.252 penduduk, sumur gali terlindungi sebanyak 155 penduduk, sumur bor dengan pompa sebanyak 124 penduduk dan mata air terlindungi sebesar 29 penduduk. Jika dilihat dari kasus diare yang ada di Puskesmas Tambang Emas tahun 2019 menunjukkan bahwa kasus diare tertinggi terdapat di Desa Tambang Emas yaitu sebanyak 654 kasus. Cakupan air bersih yang ada di Desa Tambang Emas 68,75\%.

Untuk mendapatkan air sehat, perlu dilakukan serangkaian proses pengolahan. Proses pengelolaan air minum rumah tangga yaitu penyaringan/filtrasi, klorinasi, floakulasi/disinfeksi, sodis dan merebus. Merebus air adalah cara paling umum dilakukan untuk mendapatkan air minum yang sehat. Dengan merebus air sampai mendidih dan membiarkan selama beberapa menit kemudian, maka kuman-kuman di dalam akan mati. Cara merebus air yang benar harus memasak air sampai mendidih dalam wadah yang bersih, terutup, air yang telah diolah disaring, disimpan dalam wadah yang bersih, tertutup, dan mencuci tangan dengan sabun sebelum mengolah dan menyajikan air minum (Kemenkes, 2014).

Tujuan penelitian adalan untuk mengetahui faktor-faktor yang berhubungan dengan pengelolaan air minum rumah tangga di Desa Tambang Emas Kabupaten Merangin

\section{METODE PENELITIAN}

Penelitian ini dilakukan dengan metode kuantitatif dengan desain cross sectional untuk mengetahui faktor-faktor yang berhubungan dengan pengelolaan air minum rumah tangga di Desa Tambang Emas Kabupaten Merangin Tahun 2020. Penelitian ini telah dilakukan di Dusun Rimba Mulya Desa Tambang Emas pada bulan Juli s/d Agustus 2020. Sampel penelitian adalah ibu rumah tangga 
Journal of Healthcare Technology and Medicine Vol. 6 No. 2 Oktober 2020

Universitas Ubudiyah Indonesia

e-ISSN : 2615-109X

(IRT) di Dusun Rimba Mulya Desa Tambang Emas sebanyak 73 orang. Teknik pengambilan sampel menggunakan teknik simple random sampling. Instrumen yang digunakan adalah kuesioner. Teknik pengumpulan data dengan metode wawancara. Data dianalsis menggunakan uji statistik yaitu uji chi-square.

\section{HASIL DAN PEMBAHASAN}

Hasil analisis univariat menunjukkan bahwa 50,7\% responden memiliki perilaku baik dalam pengelolaan air minum rumah tangga, sebanyak 67,1\% responden memiliki pengetahuan baik, sebanyak 57,5\% responden memiliki sikap baik dan sebanyak $46,6 \%$ responden memiliki peran petugas kesehatan baik (Tabel 1). Hasil analisis bivariat menunjukkan bahwa ada hubungan antara pengetahuan $(\mathrm{p}=0,001)$, sikap $(\mathrm{p}=0,046)$ dan peran petugas kesehatan $(\mathrm{p}=0,045)$ dengan pengelolaan air minum rumah tangga di Desa Tambang Emas tahun 2020 (Tabel 2).

Tabel 1. Gambaran Pengetahuan, Sikap, Peran Petugas Kesehatan dan Pengelolaan Air Minum Rumah Tangga di Dusun Rimba Mulya

\begin{tabular}{lcc}
\hline \multicolumn{1}{c}{ Variabel } & Jumlah & \% \\
\hline $\begin{array}{l}\text { Pengelolaan Air Minum Rumah } \\
\text { Tangga }\end{array}$ & \\
Kurang Baik & 36 & 49,3 \\
Baik & 37 & 50,7 \\
\hline Pengetahuan & & \\
Kurang Baik & 24 & 32,9 \\
Baik & 49 & 67,1 \\
\hline Sikap & & \\
Kurang Baik & 31 & 42,5 \\
Baik & 42 & 57,5 \\
\hline Peran Petugas Kesehatan & & \\
Tidak & 39 & 53,4 \\
Ya & 34 & 46,6 \\
\hline
\end{tabular}


Journal of Healthcare Technology and Medicine Vol. 6 No. 2 Oktober 2020

Universitas Ubudiyah Indonesia

e-ISSN : 2615-109X

Tabel 2 Faktor-Faktor yang Berhubungan dengan Pengelolaan Air Minum Rumah Tangga di Dusun Rimba Mulya

\begin{tabular}{|c|c|c|c|c|c|c|c|}
\hline \multirow{3}{*}{ Variabel } & \multicolumn{4}{|c|}{$\begin{array}{c}\text { Pengelolaan Air Minum } \\
\text { Rumah Tangga }\end{array}$} & \multirow{2}{*}{\multicolumn{2}{|c|}{ Total }} & \multirow{3}{*}{ p-value } \\
\hline & \multicolumn{2}{|c|}{ Kurang Baik } & \multicolumn{2}{|c|}{ Baik } & & & \\
\hline & $\mathbf{n}$ & $\%$ & $\mathbf{n}$ & $\%$ & $\mathbf{n}$ & $\%$ & \\
\hline \multicolumn{8}{|l|}{ Pengetahuan } \\
\hline Kurang Baik & 19 & 79,2 & 5 & 20,8 & 24 & 100 & 0,001 \\
\hline Baik & 17 & 34,7 & 32 & 65,3 & 49 & 100 & \\
\hline \multicolumn{8}{|l|}{ Sikap } \\
\hline Kurang Baik & 20 & 64,5 & 11 & 35,5 & 31 & 100 & 0,046 \\
\hline Baik & 16 & 38,1 & 26 & 61,9 & 42 & 100 & \\
\hline \multicolumn{8}{|c|}{ Peran petugas Kesehatan } \\
\hline Tidak & 24 & 61,5 & 15 & 38,5 & 39 & 100 & 0,045 \\
\hline Ya & 12 & 35,3 & 22 & 64,7 & 34 & 100 & \\
\hline
\end{tabular}

Berdasarkan hasil penelitian menunjukkan bahwa ada hubungan antara pengetahuan dengan pengelolaan air minum rumah tangga di Desa Tambang Emas Tahun 2020. Hal ini didasarkan pada hasil analisis dengan uji chi-square diperoleh nilai $p$-value $=0,001(p$-value $<0,05)$.

Hasil penelitian ini sejalan dengan penelitian yang dilakukan oleh Putri Afriana \& Rachmalia (2016) menunjukkan bahwa pengelolaan air minum rumah tangga dipengaruhi oleh pengetahuan $(\mathrm{p}=0,001)$. Hasil penelitian Rita Gusmiati (2016) juga menunjukkan hal yang sama bahwa capaian STBM di Kecamatan Patamuan Kabupaten Padang Pariaman dipengaruhi oleh pengetahuan ( $\mathrm{p}=0,002)$.

Perilaku seseorang yang berhubungan dengan kesehatan dipengaruhi oleh tiga faktor yaitu faktor predisposisi yaitu pengetahuan, sikap, kepercayaan, keyakinan dan motivasi, faktor pendukung yaitu peraturan kesehatan, fasilitas dan sarana kesehatan dan faktor pendorong yaitu sikap dan perilaku petugas kesehatan (Notoatmodjo, 2012). Pengetahuan dan sikap merupakan faktor yang sangat penting untuk terbentuknya tindakan seseorang, pengetahuan dan sikap ibu yang didasarkan dengan pemahaman yang tepat dapat menumbuhkan perilaku baru 
Journal of Healthcare Technology and Medicine Vol. 6 No. 2 Oktober 2020

Universitas Ubudiyah Indonesia

e-ISSN : 2615-109X

yang baik tentang suatu hal, khususnya mengenai perilaku sadar gizi pada keluarganya (Notoatmodjo, 2010).

Hasil penelitian menunjukkan bahwa ada hubungan antara pengetahuan dengan pengelolaan air minum rumah tangga di Desa Tambang Emas. Responden yang memiliki pengetahuan kurang baik akan lebih tidak mengelola air minum rumah tangga dengan baik. Hal tersebut dikarenakan bahwa responden tidak mengetahui bahwa air minum yang akan diminum harus dikelola dengan baik, karena ketidaktahuan itu maka responden tidak mengelola air minum rumah tangga dengan baik. Sedangkan responden yang memiliki pengetahuan baik tentang pengelolaan air minum rumah tangga maka ia akan melakukan pengelolaan air minum rumah tangga dengan baik. Kurangnya pengetahuan yang dimiliki oleh responden dikarenakan belum mendapatkan informasi tentang pengelolaan air minum dari petugas kesehatan, faktor pendidikan dan aktivitas diluar rumah.

Untuk meningkatkan pengetahuan masyarakat tentang pengelolaan air minum rumah tangga sebaiknya puskesmas melakukan pemberdayaan kepada masayarakat dengan metode pemicuan dikenal dengan program STBM yang mempunyai 5 pilar salah satunya adalah pengelolaan air minum rumah tangga (PAM RT). Sehingga pengetahuan masyarakat tentang PAM RT meningkat dan memiliki kemauan, kemampuan serta merubah perilaku dalam pengelolaan air minum rumah tangga.

Berdasarkan hasil penelitian menunjukkan bahwa ada hubungan antara sikap dengan pengelolaan air minum rumah tangga di Desa Tambang Emas Tahun 2020. Hal ini didasarkan pada hasil analisis dengan uji chi-square diperoleh nilai p-value $=0,046(p$-value $<0,05)$. Hasil penelitian ini sejalan dengan penelitian yang dilakukan oleh Putri Afriana \& Rachmalia (2016) menunjukkan bahwa pengelolaan air minum rumah tangga dipengaruhi oleh pengetahuan dan sikap $(\mathrm{P}=0,021)^{4}$. Hasil penelitian Rita Gusmiati (2016) juga menunjukkan hal yang sama dimana salah satu faktor yang mempengaruhi capaian STBM di Kecamatan Patamuan Kabupaten Padang Pariaman adalah sikap ( $\mathrm{p}=0,002)$.

Sikap dalam penelitian ini adalah tanggapan ibu rumah tangga terhadap cara pengelolaan air minum rumah tangga. Penelitian ini menunjukkan bahwa ada 
Journal of Healthcare Technology and Medicine Vol. 6 No. 2 Oktober 2020

Universitas Ubudiyah Indonesia

e-ISSN : 2615-109X

hubungan antara sikap dengan pengelolaan air minum rumah tangga di desa Tambang Emas. Hal tersebut dikarenakan responden mempunyai keyakinan bahwa mengelola air minum dengan baik dapat menghindarkan dari penyakit seperti diare. Kepercayaan merupakan salah satu aspek sikap yang mempresentasikan informasi tentang perilaku yang diambil, ekpektasi normatif dari lingkungan terdekat, dan kesulitan yang dialami untuk menampilkan perilaku tersebut (Notoatmodjo, 2012). Responden yang memiliki kepercayaan kuat tentang keuntungan mengelola air minum dengan baik dan benar akan memiliki sikap yang positif terhadap pengelolaan air minum rumah tangga. Responden beranggapan bahwa air minum yang dia minum dengan keluarga sudah ia kelola dengan baik dan menimbulkan keuntungan, misalnya terhindar dari penyakit diare.

Hasil penelitian juga diketahui bahwa responden memiliki sikap kurang baik tetapi mengelola air minum rumah tangga dengan baik. hal tersebut dikarenakan bahwa responden menggunakan air minum isi ulang. Responden langsung menggunakan galon untuk tempat penyimpanan air minum. Sehingga secara tidak langsung responden memiliki perilaku yang baik dalam pengelolaan air minum rumah tangga dimana tempat penyimpanan air minum harus memiliki kran atau bermulut sempit untuk menghindari kontaminasi oleh tangan dan kuman yang dapat masuk.

Berdasarkan hasil penelitian menunjukkan bahwa ada hubungan antara peran petugas kesehatan dengan pengelolaan air minum rumah tangga di Desa Tambang Emas Tahun 2020. Hal ini didasarkan pada hasil analisis dengan uji chi-square diperoleh nilai $p$-value $=0,045$ ( $p$-value $<0,05)$. Hasil penelitian ini sejalan dengan penelitian Rita Gusmiati (2016) yang diperoleh hasil bahwa capaian STBM di Kecamatan Patamuan Kabupaten Padang Pariaman dipengaruhi oleh petugas kesehatan $(\mathrm{P}=0,000)$.

Semua petugas kesehatan baik dilihat dari jenis dan tingkatannya pada dasarnya adalah pendidik kesehatan, ditengah-tengah masyarakat petugas kesehatan menjadi tokoh panutan atau kelompok referensi dari perilaku masyarakat untuk itu maka petugas kesehatan harus mempunyai sikap dan perilaku yang sesuai dengan nilai-nilai kesehatan demikian pula petugas-petugas 
Journal of Healthcare Technology and Medicine Vol. 6 No. 2 Oktober 2020

Universitas Ubudiyah Indonesia

e-ISSN : 2615-109X

lain atau tokoh masyarakat, mereka juga merupakan panutan perilaku termasuk perilaku kesehatan. Menurut Setiadi (2008), Peran petugas kesehatan adalah suatu kegiatan yang diharapkan dari seorang petugas kesehatan yang memberikan pelayanan kesehatan kepada masyarakat untuk meningkatkan derajat kesehatan masyarakat.

Dalam Undang-undang (UU) tentang Tenaga Kesehatan (UU No. 36 Tahun 2014) disebutkan bahwa tenaga kesehatan adalah setiap orang yang mengabdikan diri dalam kesehatan serta memiliki pengetahuan dan atau ketrampilan melalui pendidikan di bidang kesehatan yang untuk jenis tertentu memerlukan kewenangan untuk melakukan upaya kesehatan. Dukungan tenaga kesehatan merupakan bentuk pelayanan perannya untuk mencapai tujuan pembangunan kesehatan. Harapan masyarakat bila berhadapan dengan tenaga kesehatan adalah dapat memberikan solusi untuk menyelesaikan masalah kesehatannya baik keluhan hal yang mendasar sampai hal-hal yang komplikasi ditanyakan kepada mereka. Peran tenaga kesehatan ini juga segala peran dan tundakan dari tenaga kesehatan yang berhubungan langsung dengan masyarakat dalam hal yang bekaitan dengan kesehatan baik itu peran secara langsung dengan kondisi kesehatan seseorang maupun peran dalam hal dukungan dalam bentuk program kebijakan dibidang kesehatan.

Peran tenaga kesehatan di puskesmas sangatlah dibutuhkan bagi masyarakat yang ada di daerah lingangan kerjanya, dan tenagakesehatan sangatlah dibutuhkan untuk melakukan suatu penyuluhan kesehatan lingkungan, agar masyarakat tau dan mau untuk mengubah perilaku tidak bersih menjadi perilaku bersih (Notoatmodjo, 2012). Peran lainnya adalah sosialisasi perilaku kesehatan dirumah tangga keseluruh rumah tangga yang ada di desa atau kelurahan melalui kelompok dasawisma. Kegiatan lain yang dilakukan adalah memberdayakan keluarga untuk melaksanakan perilaku kesehatan melalui penyuluhan perorangan, kelompok, penyuluhan massa dan penggerakan masyarakat. Peran lainnya adalah mengembangkan kegiatan-kegiatan yang mendukung terwujudnya rumah tangga sehat. Memantau pencapaian rumah tangga sehat di wilayahnya setiap tahun melalui pencatatan rumah tangga, sosialisasi kesekolah-sekolah tentang perilaku hidup bersih dan sehat (Mulia, 2005). 
Journal of Healthcare Technology and Medicine Vol. 6 No. 2 Oktober 2020

Universitas Ubudiyah Indonesia

e-ISSN : 2615-109X

Hasil penelitian menunjukkan bahwa ada hubungan antara peran tenaga kesehatan dengan pengelolaan air minum rumah tangga. Petugas kesehatan tidak memberikan penyuluhan, sosialisasi dan konseling kepada responden maka responden tidak mendapatkan informasi tentang pengelolaan air minum rumah tangga, pengetahuan yang kurang baik menyebabkan responden tidak melakukan pengelolaan air minum rumah tangga yang baik. Sedangkan responden yang menyatakan peran petugas kesehatan baik maka akan melakukan pengelolaan air minum rumah tangga yang baik. hal tersebut dikarenakan petugas kesehatan memberikan konseling kepada responden sehingga meningkatkan pengetahuan responden dan merubah perilaku responden dalam pengelolaan air minum rumah tangga.

Hasil penelitian juga terdapat bahwa responden peran petugas kesehatan kurang baik tetapi melakukan pengelolaan air minum rumah tangga baik, hal tersebut dikarenakan responden memiliki dukungan keluarga yang baik diman keluarga selalu mengingatkan untuk mengolah air minum seperti merebusnya terlebih dahulu sebelum digunakan untuk minum, mengingatkan untuk mencuci tempat penampungan air minum dengan air yang sudah dimasak.

Untuk meningkatkan peran tenaga kesehatan dalam pengelolaan air minum rumah tangga sebaiknya kepala puskesmas melakukan evaluasi terhadap kegiatan kesehatan lingkungan khususnya tentang pengelolaan air minum rumah tangga yang sudah dilakukan. Kepala puskesmas memberikan pelatihan kepada kader dalam program pemberdayaan masyarakat melalui pemicuan STBM sehingga kader dapat membantu puskesmas dalam melakukan pemicuan pengelolaan air minum rumah tangga kepada masyarakat yang ada di wilayah kerjanya.

\section{KESIMPULAN}

Berdasarkan hasil penelitian diketahui bahwa faktor yang berhubungan terhadap pengelolaan air minum rumah tangga adalah pengetahuan, sikap dan peran petugas kesehatan.

\section{SARAN}


Journal of Healthcare Technology and Medicine Vol. 6 No. 2 Oktober 2020

Universitas Ubudiyah Indonesia

e-ISSN : 2615-109X

Untuk meningkatkan pengetahuan masyarakat sebaiknya puskesmas melakukan pemicuan tentang pengelolaan air minum rumah tangga.

\section{DAFTAR PUSTAKA}

Afriana, P., \& Rachmalia. (2016). Pengolahan Air Minum Dengan Masalah Kesehatan Terkait Penggunaan Air Minum Di Aceh Besar. Junal Kesehatan Masyarakat, 6(1), 1-6.

Gusmiati, R. (2018). Gambaran Pengetahuan, Sikap, dan Petugas Kesehatan Dalam Capaian Lima Pilar Sanitasi Total Berbasis Masyarakat Di Kecamatan Patamuan Tahun 2016. Jurnal Kesehatan Prima Nusantara Bukittinggi, 9(1), 26-32.

Kemenkes. (2014). Peraturan Menteri Kesehatan Republik Indonesia Nomor 3

Tahun 2014 Tentang Sanitasi Total Berbasis Masyarakat. Jakarta: Kementerian Kesehatan Republik Indonesia.

Kemenkes. (2015). Kurikulum dan Modul Pelatihan Sanitasi Total Berbasis Masyarakat (STBM). Jakarta: Kementerian Kesehatan Republik Indonesia.

Kemenkes. (2019). Profil Kesehatan Indonesia Tahun 2018. Jakarta: Kementerian Kesehatan Republik Indonesia.

Mulia, R. (2005). Kesehatan Lingkungan. Yogyakarta: Graha Ilmu

Notoatmodjo, S. (2010). Promosi Kesehatan Teori dan Aplikasi. Jakarta. Retrieved from Rineka Cipta

Notoatmodjo, S. (2012). Promosi Kesehatan dan Ilmu Perilaku. Jakarta: Rineka Cipta. 